\title{
MEMAHAMI EKSPRESI EMOSIONAL MELALUI BAHASA VISUAL DALAM BUKU CERGAM ANAK "LITTLE GREY”
}

\author{
Diani Apsari ${ }^{1}$, Wibisono Tegar Guna Putra ${ }^{2}$ \\ 1,2Program Studi Desain Komunikasi Visual, Fakultas Industri Kreatif, Telkom University, \\ Jl. Telekomunikasi, Bandung, Jawa Barat, 40257 \\ dianiapsari@telkomuniversity.ac.id; wibisonogunaputra@telkomuniversity.ac.id
}

\begin{abstract}
Abstrak: Anak adalah individu yang bertumbuh dan berkembang dengan berbagai emosi yang ada di sekitarnya. Di antaranya adalah rasa senang yang berkaitan erat dengan fenomena kegembiraan, rasa marah yang erat dengan rasa terganggu, serta rasa duka yang erat kaitannya dengan fenomena kehilangan. Merasakan kesedihan melalui kehilangan orang yang dicintai, menjadi peristiwa yang seringkali ditemui dalam kehidupan sehari-hari. Sebagaimana orang dewasa, anak-anak juga dirasa perlu untuk memahami bagaimana ketika emosi, termasuk rasa duka tersebut muncul. Salah satu cara agar anak dapat memahami situasi tersebut adalah dengan mengenalkannya dalam buku cerita bergambar. Buku cerita bergambar yang baik adalah yang menerapkan pendekatan visual yang sesuai dengan perkembangan usia dan imajinasi anak, sesuai dengan aspek kognitif dan sosio-emosional. Pemahaman akan imajinasi anak dapat dilakukan dengan mengamati gambar yang mereka kreasikan, karena gambar anak merupakan visualisasi dari apa yang indra-indra mereka alami dan rasakan. Bahasa visual khas anak tersebut dapat ditemukan penerapannya dalam buku cergam anak, yang dalam objek penelitian ini adalah buku cergam anak berjudul "Little Grey". Melalui kajian terhadap hasil kreasi gambar anak dan ilustrasi dalam buku cergam anak "Little Grey" serta kesesuaiannya terhadap perkembangan psikologi dan bahasa visual usia pembaca "Little Grey", penelitian ini bermaksud menganalisa bagaimana hubungan bahasa visual antara gambar anak dalam mengungkapkan emosinya dan ilustrasi yang termuat dalam buku cergam anak, sehingga dapat menjadi bahan pertimbangan para kreator buku anak dalam membuat visual buku anak yang sesuai dengan perkembangan anak sebagai pembacanya. Kata kunci: Pemahaman emosi, bahasa visual anak, ilustrasi, buku cergam anak
\end{abstract}

Abstract: Children are individuals who grow and develop with various emotions around them. Among them is the feeling of happiness, which is closely related to the phenomenon of excitement, the feeling of anger that is closely related to the sense of annoyance, and the sense of grief that is closely related to the phenomenon of loss. Feeling sadness through the loss of a loved one becomes an event that is often encountered in everyday life. Like adults, children also feel the need to understand how to deal with emotions, including how the grief arises. One way for children to understand the situation is to introduce it in picture story books. A good picture book is one that incorporates a visual 
approach that is suitable to the children's age and imagination, in accordance with emotional and cognitive aspects. Understanding children's creativity can be achieved by studying the drawings they create, as children's drawings are visualizations of what their senses perceive and feel. The familiar concept of children visual language can be found in published picture book, which is the topic of this analysis is in a children's picture book titled Little Grey. Through a study from the results of the creation of children's drawings and illustrations in "Little Grey" as well as its suitability for the development of psychology and visual language of its reader category, this study intends to analyze how the relationship of visual language between children's images in expressing their emotions, and illustrations contained in a children's picture book, so that it can be taken into consideration by the creators of children's books in making visuals that are appropriate to the children as a reader.

Keywords: Emotion understanding, visual language, illustration, children's picture book.

\section{PENDAHULUAN}

Anak-anak tumbuh dan berkembang dengan berbagai emosi di sekitarnya. Saarni, Mumme, dan Campos, dalam Berk (2013) menyatakan, emosi mengekspresikan kesiapan anak untuk membangun, mempertahankan, atau mengubah hubungan anak dengan lingkungan, dan seiring perkembangan kognitif, afektif, dan sosio-emosionalnya, secara perlahan anak-anak dapat memahami emosi-emosi tersebut.

Salah satu emosi yang akan dihadapi seorang anak dalam hidupnya adalah rasa sedih dan duka cita, karena kejadian ini tidak dapat dihindarkan dalam hidup. Konsep abstrak seperti emosi dapat dipahami dengan melatih anak berimajinasi, dan memahami imajinasi anak dapat dilakukan dengan mengamati gambar yang mereka kreasikan karena gambar anak merupakan visualisasi dari apa yang inderaindera mereka alami dan rasakan, fenomena ini disebut bahasa visual anak (Tabrani, 2012).

Buku cergam anak adalah salah satu media komunikasi yang dapat menerapkan bahasa visual anak di dalamnya, apalagi dilengkapi kenyataan bahwa anak tumbuh di dalam dunia yang dipenuhi unsur visual sehingga mereka lebih cepat menangkap informasi dalam bentuk kode-kode visual (Salisbury, 2004). Maka dari itu, semakin dini seorang anak membaca buku cerita bergambar, dapat 
membantu anak-anak dalam membayangkan dan belajar tentang fenomena keseharian yang akan mereka hadapi.

Salah satu buku cergam anak yang beredar di pasaran adalah buku cergam "Little Grey" yang ditulis oleh Shevani Thalia dan diilustrasikan oleh Diani Apsari di tahun 2018. Buku cergam anak ini memiliki target pembaca di rentang usia 6-11 tahun.

Berdasarkan penelitian sebelumnya, yang telah ditulis oleh Hanisha, Djalari dan Hutama, yang mengkaji hubungan antara bahasa visual dan ilustrasi yang ada di dalam buku cergam anak dengan rentang usia pembaca yang sama yaitu, "Kerlip Bintang di Langit" karya Clara Ng dan EmTe, penelitian tersebut menghasilkan bahwa gaya visual anak-anak mempengaruhi gaya ilustrasi yang ada di dalam buku anak (Hanisha, Djalari dan Hutama, 2018). Akan tetapi, penelitian tersebut belum membuktikan apakah visual tersebut berkaitan juga dengan pemahaman emosi yang dihadirkan dalam buku cergam anak. Selain itu, ada juga penelitian yang dilakukan oleh Novia, Waluyanto, dan Zacky, berjudul "Perancangan Buku Bergambar Dengan Daya Tarik Pop-Up Tentang Manajemen Emosi Untuk AnakAnak Usia 4-6 Tahun". Dalam penelitian ini diungkapkan bahwa visual bertema fantasi cocok untuk mengkomunikasikan emosi, terutama emosi marah, bagi anak-anak (Novia, Waluyanto dan Zacky, 2016), akan tetapi rentang usia yang dibahas dalam penelitian tersebut terbatas pada anak usia TK saja (usia 4-6 tahun). Selain itu, rentang emosi yang dibahas hanya sebatas emosi marah saja, tetapi tidak membahas emosi dasar yang lain, seperti perasaan senang maupun sedih.

Maka dari itu, penelitian ini diadakan untuk mengkaji korelasi antara bahasa visual pada gambar anak dan ilustrasi buku cergam anak dengan memperhitungkan aspek perkembangan psikologi dan sosio-emosional yang terjadi sesuai usia pembaca "Little Grey" yaitu usia 6-11 tahun.

Anak-anak dan Asal Mula Pemahaman Konsep Kedukaan 
Dalam tatanan masyarakat, sebetulnya konsep sedih dan duka adalah kejadian yang tidak dapat dihindari. Setiap orang mengalami apa yang disebut siklus kehidupan, dari lahir, menjadi dewasa, lalu pada akhirnya meninggal. Van Gennep mengungkapkan, ada konsep ritus peralihan yaitu, kategori ritual yang menandai peralihan seseorang melalui siklus kehidupan (van Gennep et al., 2018). Dimulai dari sesederhana upacara perayaan ketika bayi lahir dan belajar berjalan, lalu perayaan ulang tahun, pernikahan, dan ritual yang dijalankan ketika ada anggota keluarga yang meninggal, anak-anak belajar menyikapi kejadian tersebut dengan pemahaman emosi yang berkembang sesuai emosinya, termasuk perasaan sedih dan berduka. Melalui perspektif kebudayaan, kehilangan yang terepresentasi melalui kematian, pada akhirnya merupakan salah satu fase hidup yang tidak dapat dihindari secara biologis, sekaligus bagian dari proses transisi dan belajar.

Perspektif lain dikemukakan oleh Burns, dalam (Howard, 2010) yaitu persepsi dan tanggapan anak-anak terhadap rasa duka dibentuk oleh interaksi dinamis antara perkembangan dan tekanan sosial. Lalu, interaksi ini berubah seiring waktu. Khususnya dalam kisaran 6-11 tahun, anak-anak menemukan diri mereka dalam tahap transisional yang sangat sensitif akan perubahan, ada anak yang dapat terlihat mandiri dan menyamarkan rasa sakit mereka atau bahkan sangat sulit mengungkapkan rasa duka tersebut sehingga berdampak bagi keadaan emosional mereka (Steyn dan Moen, 2019).

\section{Psikologi Perkembangan dan Emosi Anak}

Kedukaan ini kemudian coba dihubungkan dengan aspek psikologi perkembangan anak. Secara garis besar, perkembangan anak meliputi tiga aspek yaitu: Perkembangan Fisik; Perkembangan Kognitif; lalu yang terakhir adalah Perkembangan Sosio-Emosional, yang melibatkan perkembangan emosi dari anak, eksplorasi perasaan, kemampuan interpersonal, hubungan antar manusia, bahkan 
konsep moral. Semua aspek perkembangan ini berjalan secara terintegrasi dan paralel, sesuai dengan bertambahnya usia anak (Berk, 2013).

Aspek perkembangan ini pun dibagi oleh Piaget (AD, 2018), dalam empat tahap, yaitu: (1) Tahap Sensorimotor, (2) Tahap Pra-operasional, (3) Tahap Operasional Konkrit, dan (4) Tahap Operasional Formal. Sehingga, pada tahapan usia 6-11 tahun, atau Tahap Operasional Konkret, anak dianggap sudah dapat mengerti dan mampu menangkap isi dari buku cerita bergambar.

Selain itu, berkaitan dengan topik penelitian, yaitu berkaitan dengan usia 6-11 tahun, ada suatu tahapan perkembangan emosi yang dapat dijabarkan dalam dua bagian, yaitu pengekspresian emosi, serta pemahaman emosi. Pengekspresian dan pemahaman emosi yang dipahami oleh anak usia 6-11 tahun adalah, mulai muncul rasa empati yang dapat semakin meningkat sesuai bertambahnya umur (Gerber, Wilks dan Erdie-Lalena, 2011). Selain itu, seiring bertambahnya perbendaharaan bahasa, anak dapat lebih memahami dirinya melalui emosi, sehingga berangsur dapat meregulasi perilakunya, karena anak tersebut dapat mengekspresikannya (Bariola, Gullone dan Hughes, 2011). Konsep tentang emosi ini, selain dibina dari caregiver anak-anak tersebut di lingkungannya, dapat dikenalkan melalui media komunikasi seperti misalnya buku cergam anak.

\section{Cergam Anak dan Temanya}

Selain menawarkan wawasan visual dan narasi serta pengembangan aspek kognitifnya, buku cergam anak dengan pangsa pasar usia yang lebih tua juga dapat menawarkan tema-tema yang lebih sensitif. Tema-tema sensitif yang ada dalam buku anak pun tentunya berkaitan dengan penggambaran ilustrasi dan teks yang disampaikan untuk menarasikan tema sulit, seperti pemahaman emosi, atau bahkan konsep kedukaan dan kematian (Indrayati, Setyawan dan Saidi, 2018). Tentu saja, buku-buku cergam anak dengan tema yang lebih sulit dicerna ini harus dibaca dengan memperhitungkan kematangan perkembangan psikologis dan 
emosi dari anak-anak dan dilengkapi pengawasan dari orangtua atau pengasuhnya.

Dalam McCannon, Thonton dan Williams (2008), selain mengangkat tema budaya, mitos dan tradisi yang disampaikan turun temurun dari generasi ke generasi, perasaan dan emosi anak juga sering dijadikan tema buku cergam anak, salah satunya konsep Sadness (Kesedihan) dan Loss (Kehilangan). Sadness and Loss biasanya berfokus pada rasa kehilangan yang terjadi dalam kehidupan anak-anak. Konsep tentang kesedihan dan kehilangan ini dapat dikemas dengan narasi dan visual yang akrab dengan dunia anak-anak, dengan tujuan pembaca dapat merelasikan apa yang disampaikan dalam buku tersebut ke dalam kehidupannya.

\section{Fungsi ilustrasi dalam Buku Cergam Anak}

Ross, dalam Salam (2017) mengungkapkan bahwa seni ilustrasi adalah sebuah presentasi yang mencerminkan kepribadian seseorang dalam bentuk karya hitam-putih atau multiwarna yang selalu menggairahkan, membangkitkan semangat, menggugah perasaan, dan membangkitkan motivasi. Ilustrasi pun bertindak sebagai mediator antara teks dan pembaca, memungkinkan pembaca "merasakan kata-kata" (Hladíková, 2014). Menurut Kartaatmadja (2015), ilustrasi memiliki peran yang sangat penting karena menilik sensitivitas seorang anak terhadap gambar (visual) yang bahkan telah muncul sebelum anak dapat berbicara.

Maka dari itu, bagi anak-anak, dengan mengetahui ada sebuah buku cergam yang dapat menggambarkan persoalan hidup mereka dengan baik membuat mereka merasa tidak sendiri. Gambaran persoalan kehidupan tersebut dapat dikemas dalam narasi cerita dan ilustrasi. Sebuah karakter yang dibentuk dari narasi yang ada di dalam cergam, disertai visual yang menarik akan membangun keterikatan dengan para pembaca (McCannon, Thonton dan Williams, 2008).

\section{Proses Menggambar yang Dilakukan oleh Anak}


Cara mengetahui visual apa yang menarik bagi anak adalah dengan mencari tahu bagaimana cara anak menanggapi dunia di sekitarnya. Ternyata, cara anak melihat dan menggambar berbeda dengan orang dewasa (Tabrani, 2012:13). Hal ini terkait dengan pertumbuhan, perkembangan dan pematangan integrasi pada indra, imaji, susunan syaraf dan cara berpikir anak, lalu dicetuskan menjadi gambar. Sehingga, proses kegiatan menggambar dianggap lebih penting bagi anak daripada hasil gambar anak itu sendiri.

Perkembangan seni rupa anak telah diteliti oleh beberapa tokoh, di antaranya adalah Viktor Lowenfeld. Periodesasi perkembangan gambar anak menurut Lowenfeld (dalam Streit, 2012) adalah (1) Masa Coreng-Moreng/ Scribbling, usia 2-4 tahun (2) Masa Pra-bagan/ Preschematic, 4-7 tahun; (3) Masa Bagan/ Schematic Period, 7-9 tahun; (4) Masa Realisme Awal/ Early realism, usia 9-12 tahun; (5) Masa Naturalisme Semu/ Pseudo Naturalistic, usia 12-14 tahun; dan (6) Masa Penentuan/ Period of Decision, usia 14-17 tahun. Semua ini sangat berpengaruh dalam cara anak memvisualisasikan idenya dalam bentuk gambar.

Schematic Period/ Masa Bagan adalah yang menjadi fokus dalam Penelitian ini, yaitu merupakan masa dimana anak mulai menggambar objek dalam suatu hubungan yang lebih logis dengan objek yang lain. Apalagi, di antara usia 6-10 tahun merupakan masa keemasan ekspresi kreatif (Inarah, 2017). Adapun konsep sistem yang sering dipergunakan dalam gaya visual anak adalah adalah sistem RWD (Ruang Waktu Datar) dan sistem NPM (Naturalis Perspektif Momen-Opname).

Terlihat pada Tabel 1 mengenai skema perkembangan Bahasa Rupa dan Gambar Anak yang dijelaskan lebih rinci seperti berikut ini: 
Tabel 1. Skema Perkembangan Bahasa Rupa dan Gambar Anak

\begin{tabular}{|c|c|c|}
\hline Usia & Perkembangan Gambar & Perkembangan Bahasa-Rupa \\
\hline $2-3$ & Coreng-Moreng tanpa arti & $\begin{array}{l}\text { Baru merupakan sensasi jejak } \\
\text { jemari. }\end{array}$ \\
\hline $3-4$ & Coreng-Moreng mulai ada arti & $\begin{array}{l}\text { Ruang angkasa, aneka waktu, } \\
\text { aneka ruang }\end{array}$ \\
\hline $4-5$ & Mementingkan bagian tertentu objek & $\begin{array}{l}\text { +, Digeser, Dinamis, Aneka } \\
\text { arah/jarak/waktu, tampak } \\
\text { khas, bagian objek tertentu } \\
\text { diperbesar, yang lain diabaikan }\end{array}$ \\
\hline $5-6$ & Skema sederhana, konsep atas-bawah & $\begin{array}{l}+ \text {, atas-bawah, tepi bawah } \\
\text { kertas = garis tanah }\end{array}$ \\
\hline $6-7$ & $\begin{array}{l}\text { Perkembangan skema, seiring perkembangan } \\
\text { integrasi indera. } \\
\text { Perkembangan konsep ruang \& waktu. }\end{array}$ & $\begin{array}{l}\text { + garis tanah, belum ada } \\
\text { perspektif, disederhanakan } \\
\text { (distilir). } \\
\text { Berbagai bahasa-rupa } \\
\text { digunakan sekaligus, Kepala - } \\
\text { Kaki }\end{array}$ \\
\hline $7-8$ & Utamakan objek yang dipentingkan & $\begin{array}{l}\text { +, Objek yang penting } \\
\text { diperbesar, Sinar } X\end{array}$ \\
\hline $8-9$ & Aneka waktu dan ruang & $\begin{array}{l}\text { +, Lapisan Latar, Garis tanah } \\
\text { Jamak, Kembar, Imaji Jamak, } \\
\text { Rebahan, Berkeliling, Kesan } \\
\text { Datar dan Dekoratif }\end{array}$ \\
\hline $9-10$ & Mata mulai lebih berperan semula lebih untuk rinci & $\begin{array}{l}+ \text {, Detail lebih rinci dari objek } \\
\text { yang digambar }\end{array}$ \\
\hline $10-11$ & $\begin{array}{l}\text { Gambar selain hasil imajinasi, mulai merupakan } \\
\text { catatan peristiwa. }\end{array}$ & $\begin{array}{l}\text { Seakan naturalis, tapi sekaligus } \\
\text { digunakan aneka bahasa visual } \\
\text { tersebut di atas }\end{array}$ \\
\hline $11-13$ & $\begin{array}{l}\text { Masa krisis, saat terjadi "perang" antara indera mata } \\
\text { yang baru jadi dengan indera-indera lainnya. }\end{array}$ & $\begin{array}{l}\text { Ciri: Muncul gambar ruang } \\
\text { tumpang tindih-overlapping. } \\
\text { Anak bingung diantara sistem } \\
\text { RWD dengan sistem NPM. }\end{array}$ \\
\hline
\end{tabular}

(Sumber: Tabrani, 2012)

\section{Aspek Penggunaan Warna dalam Pengekspresian Emosi}

Sebuah kombinasi warna yang dirancang sedemikian rupa, dapat membangkitkan atau membantu visualisasi emosi tertentu (Dyah RA., 2017), dalam hal ini termasuk visualisasi yang ada di dalam buku cergam anak. Dalam hal ini contohnya adalah penggunaan warna dengan full saturation yang menampilkan kesan panas yang sangat kuat menampilkan keagresifan sehingga sering digunakan untuk mengekspresikan kemarahan. Contoh lain adalah 
penggunaan warna biru menjadi skema warna utama untuk menciptakan warna tenang. Warna dingin yang diberikan sedikit warna putih, akan menciptakan rasa damai, sehingga cocok ditampilkan dalam menampilkan ketenangan. Warnawarna gelap seperti hitam pun sering ditampilkan sebagai warna misterius yang dihubungkan dengan ketakutan atau perasaan berduka (Basuki, 2015). Paduan warna ini jika ditampilkan dengan tepat bersamaan dengan visual yang dipahami oleh anak, dapat mengkomunikasikan konsep yang abstrak termasuk di antaranya adalah konsep emosi.

\section{METODE PENELITIAN}

Penelitian merupakan penelitian kualitatif deskriptif, yaitu penelitian berupa kajian pada aspek nonteknis yang menjelaskan relasi antara bahasa visual anak dengan pemahaman atas visualisasi rasa sedih serta ilustrasi yang ada di dalam buku cergam anak "Little Grey". Mengenai pengumpulan data, yang dilakukan adalah studi literatur yang mana mengacu dari penelitian dan perancangan sebelumnya yang mempunyai ekspresi emosi yang ada di dalam buku cergam anak, sebaiknya mengacu pada bagaimana anak mengekspresikan emosinya melalui gambar. Adapun penelitian Claudia E.Novia, Heru Dwi Waluyanto, dan Asnar Zacky (Novia, Waluyanto dan Zacky, 2016) berjudul “Perancangan Buku Bergambar Dengan Daya Tarik Pop-Up Tentang Manajemen Emosi Untuk Anak-Anak Usia 4-6 Tahun." turut membahas tentang pemahaman emosi, namun mengambil sampel penelitian dengan rentang usia pembaca/ target perancangan yang lebih muda, yaitu anak-anak usia 4-6 tahun. Kedua judul penelitian ini sama-sama membahas keterkaitan bahasa visual dengan pemahaman ungkapan emosional. Fokus riset penelitian ini secara garis besar akan merangkum tahapan-tahapan yang telah dianalisa dari penelitian sebelumnya, dan mengobservasi gambar yang dihasilkan oleh anak-anak, serta survey kepada anak-anak yang telah membaca buku cergam anak "Little Grey" 
dengan rentang usia 6-11 tahun. Analisis menggunakan analisis konten untuk mengungkapkan bagaimana korelasi antara bahasa visual pada gambar anak dan ilustrasi buku cergam anak dengan memperhitungkan aspek perkembangan psikologi yang terjadi sesuai usianya.

\section{HASIL DAN DISKUSI}

\section{Little Grey}

Buku cergam anak "Little Grey" rilis di bulan Desember 2018, ditulis oleh Shevani Thalia dan diilustrasikan oleh Diani Apsari, diterbitkan oleh Grasindo Indonesia. Berkisah tentang seorang anak bernama Anna, yang memiliki rambut abu-abu, serta sering disisihkan karena memiliki penampilan fisik yang berbeda dengan anak yang lain. Anna alias "Little Grey" pun berteman dengan sepasang kakek dan nenek bernama "Aunt Nina" dan "Uncle Jack", tetapi di tengah cerita, Anna harus menghadapi kejadian-kejadian menyedihkan yang mengakibatkan "Aunt Nina" dan "Uncle Jack" pergi dari kehidupannya. "Little Grey" ditulis dalam narasi berbahasa Inggris, dan buku cergam anak fiksi ini diperuntukkan untuk anak usia 6 - 11 tahun. Berdasarkan hasil wawancara, Shevani Thalia membuat naskah Little Grey berdasarkan pengalaman masa kecilnya dalam menghadapi kejadian ketika neneknya meninggal ketika Shevani berusia 6 tahun.

Latar belakang Shevani Thalia menuangkan pengalaman masa kecilnya dalam bentuk buku cergam "Little Grey" dikarenakan dia berkeinginan anak-anak yang lain dapat merelasikan perasaan sedih yang sering terjadi dalam hidup, termasuk peristiwa ketika ada anggota keluarga yang meninggal. Baginya, bukubuku dengan tema yang mengangkat kesedihan seperti "Little Grey" cocok untuk dibaca oleh orangtua dan anak secara bersama-sama, karena kadang rasa sedih yang dialami anak-anak sulit untuk diungkapkan, sehingga perlu dibimbing oleh orangtua supaya bisa mengelola perasaannya. 


\section{Analisis Bahasa Visual yang Merepresentasikan Kesedihan dalam Gambar Anak}

Responden yang dipilih dalam penelitian ini adalah anak-anak yang telah membaca cergam "Little Grey", dengan rentang umur yang sesuai dengan pembaca buku cergam anak Little Grey yaitu 6-11 tahun. Dalam mengumpulkan data gambar anak ini, penulis dengan spesifik meminta kepada orangtua responden untuk menunjukkan karya gambar responden yang menunjukkan ekspresi emosi sedih.

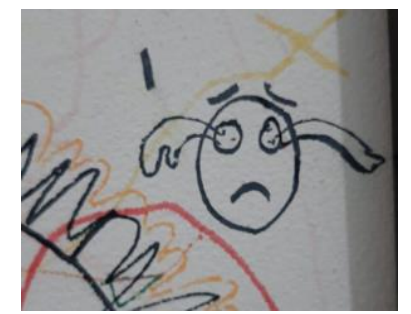

Gambar 1 Karya Adwin (6 tahun)

Dokumentasi: Nita Permata (2020)

Dalam Tabel 2, akan dijelaskan lebih lanjut mengenai pemetaan bahasa visual Gambar 1 sebagai berikut ini:

Tabel 2. Pemetaan Bahasa Visual Gambar I

\begin{tabular}{lll}
\hline Cara Wimba & Tata Ungkapan Dalam & Bahasa Visual Anak \\
\hline Penggambaran skematis pada & Objek yang penting & Menggambarkan ekspresi \\
wajah; penggambaran & diperbesar; tampak sinar X & muka menangis dan \\
ekspresif pada wajah + RWD & & mengutamakan wimba kepala \\
& & manusia melalui skala; \\
& & Tampak sinar X dari “air mata” \\
& yang keluar dari objek mata. \\
\hline
\end{tabular}

(Sumber: Apsari \& Putra, 2020)

Gambar 1 merupakan gambar bertema penggambaran emosi yang dibuat oleh Adwin. Wimba kepala manusia tampak menonjol dibanding garis-garis dekoratif berwarna cerah di sampingnya dan garis yang disebut "air mata" tampak tembus pandang menembus pipi, dan garis alis yang turun membingkai mata yang kosong. 


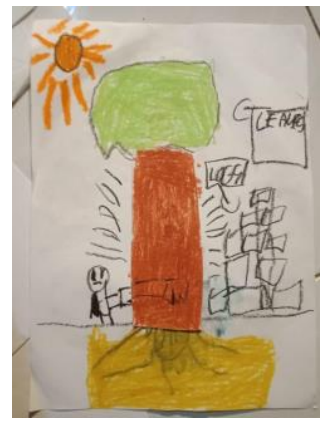

Gambar 2 Karya Khalif (7 tahun)

Sumber: Dokumentasi Puti Ceniza (2018)

Dalam Tabel 3, akan dijelaskan lebih lanjut mengenai pemetaan bahasa visual Gambar 2 sebagai berikut ini:

Tabel 3. Pemetaan Bahasa Visual Gambar 2

\begin{tabular}{lll}
\hline Cara Wimba & Tata Ungkapan Dalam & Bahasa Visual Anak \\
\hline Perkembangan skema, seiring & Objek yang penting & Utamakan wimba yang lebih \\
dengan perkembangan & diperbesar; tampak sinar X; & penting melalui skala; \\
integrasi indera. & Tampak khas; Komposisi & Menggunakan warna sebagai \\
& & identitas objek tertentu. \\
\hline
\end{tabular}

(Sumber: Apsari \& Putra, 2020)

Dalam gambar 2, terdapat bentuk pengembangan dari gambar 1, yaitu objek yang penting diperbesar, serta mulai menggunakan warna sebagai identitas objek tertentu. Dalam skema perkembangan visual anak, usia 7 tahun adalah usia dimana anak dapat memahami konsep warna. Gambar ini bercerita tentang Khalif yang merasa sedih setelah melihat banyak pohon yang ditebang dalam sebuah film dokumenter. Disini, Khalif menggunakan warna coklat untuk wimba pohon, hijau untuk wimba daun, serta coklat muda untuk wimba akar. Warna-warna yang sesuai dengan keadaannya ini (coklat untuk pohon, hijau untuk daun) sebatas menunjukkan identitas objek pohon tersebut sesuai dengan yang aslinya. Di dekat wimba pohon, ada wimba tumpukan batang pohon yang menunjukkan pohonpohon tersebut sudah ditebang. Ada wimba manusia yang membawa gergaji listrik, dengan tampak sinar $\mathrm{X}$, memotong pohon tersebut. Persepsi akan emosi sedih lebih tertangkap di ekspresi yang ditunjukkan di wimba manusia tersebut. 


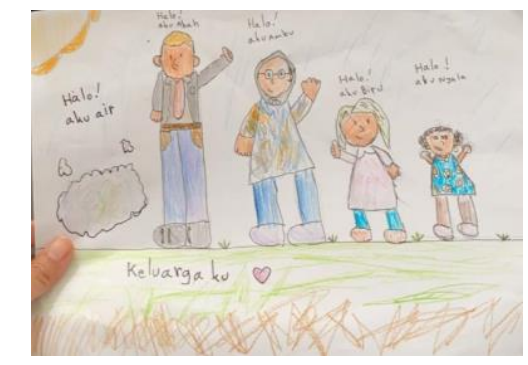

Gambar 3 Karya Biru (8 tahun)

Sumber: Dokumentasi Olva Patriani (2019)

Dalam Tabel 4, akan dijelaskan lebih lanjut mengenai pemetaan bahasa visual Gambar 3 sebagai berikut ini:

Tabel 4. Pemetaan Bahasa Visual Gambar 3

\begin{tabular}{lll}
\hline Cara Wimba & Tata Ungkapan Dalam & Bahasa Visual Anak \\
\hline Perkembangan naturalis; & Urutan di suatu latar; arah & Cara melihat latar berurutan \\
Penggambaran ekspresif pada & lihat berurutan ke samping; & ke samping, penggambaran \\
wajah; Penggambaran & Cara khas; Ada komposisi. & wajah yang ekspresif dan \\
dekoratif untuk suasana; & & wimba hati dan matahari \\
Momen opname & & untuk menciptakan suasana. \\
\hline
\end{tabular}

(Sumber: Apsari \& Putra, 2020)

Pada gambar 3, Biru menggambar foto keluarganya dengan latar belakang langit dan latar pemandangan. Ayah, Ibu, Biru, dan adiknya, Nyala digambarkan berdiri bersampingan dengan wimba awan yang diberi judul "Air" yaitu nama adik Biru yang sudah wafat beberapa tahun yang lalu. Wimba pohon, rumput, matahari yang dibuat berwarna-warni bertujuan untuk membangun suasana cerah, terlepas dari sudah wafatnya adik Biru. Setelah dilakukan wawancara lebih lanjut dengan orangtua Biru, ternyata Biru menggunakan warna biru cerah karena beranggapan mendiang adiknya selalu ada di hidupnya. Sehingga penulis beranggapan bahwa dalam gambar ini, yang berusaha ditampilkan Biru adalah emosi yang tenang, sesuai dengan warna biru dan pink lembut yang ditampilkannya.

\section{Analisis Persepsi Anak Terhadap Visualisasi Emosi Sedih}


Untuk mendampingi analisis bahasa visual anak pada gambar anak, penulis memutuskan membuat survey untuk mengetahui persepsi anak terhadap bermacam-macam visualisasi emosi "sedih" yang terdapat dalam buku cergam anak. Survey ini bertujuan mengetahui sejauh mana pemahaman responden, yaitu dalam rentang usia pembaca Little Grey, kepada variasi visual yang menunjukkan kesedihan. Di dalam Tabel 5, dapat kita lihat lebih jelas persepsi anak terhadap berbagai visualisasi emosi sedih berdasarkan sampel-sampel gambar yang menunjukkan ekspresi sedih.

Tabel 5. Persepsi Anak Terhadap Visualisasi Emosi Sedih

\begin{tabular}{|c|c|c|c|c|c|}
\hline No & Gambar & Deskripsi Gambar & Nama Anak & ia) + Des & ipsi dari anak \\
\hline & & & Riang (7) & Biru (8) & Malik Azka (10) \\
\hline 1 & $\begin{array}{c}\text { https://en.islcollective.c } \\
\text { om/english-esl- } \\
\text { worksheets/grammar/ad } \\
\text { jectives-feelings/how- } \\
\text { do-you-feel/79027 } \\
\text { [diakses tanggal } 1 \text { Maret } \\
\text { 2020] }\end{array}$ & $\begin{array}{l}\text { Close-Up + } \\
\text { Outline } \\
\text { Sederhana + } \\
\text { Hitam Putih }\end{array}$ & $\begin{array}{l}\text { "Sedih. } \\
\text { Tidak Tahu } \\
\text { Kenapa." }\end{array}$ & "Sedih" & "Sedih" \\
\hline 2 & $\begin{array}{l}\text { https://www.pngfuel.co } \\
\mathrm{m} / \text { free-png/aaxzu } \\
\text { [diakses tanggal } 3 \text { Maret } \\
\text { 2020] }\end{array}$ & $\begin{array}{l}\text { Close Up + } \\
\text { Pewarnaan } 2 \\
\text { Dimensi + } \\
\text { Background } 1 \\
\text { Warna }\end{array}$ & "Menangis" & $\begin{array}{l}\text { "Me- } \\
\text { nangis" }\end{array}$ & "Sangat sedih" \\
\hline 3 & $\begin{array}{l}\text { https://id.pinterest.com/ } \\
\text { pin/53796911796030269 } \\
\text { 7/[diakses tanggal } 1 \\
\text { Maret 2020] }\end{array}$ & $\begin{array}{l}\text { Close Up + } \\
\text { Pewarnaan } 2 \\
\text { Dimensi + } \\
\text { Pendekatan } \\
\text { Realis }\end{array}$ & "Sedih" & "Sedih" & "Patah hati" \\
\hline 4 & $\begin{array}{l}\text { https://www.dreamstim } \\
\text { e.com/cute-boy-crying- } \\
\text { cartoon-illustration- } \\
\text { tears-cute-boy-crying- }\end{array}$ & $\begin{array}{l}\text { Full Body }+ \\
\text { Pewarnaan } 2 \\
\text { Dimensi + } \\
\text { Pendekatan } \\
\text { Ilustratif + Tidak } \\
\text { ada Background }\end{array}$ & "Menangis" & "Kesal" & $\begin{array}{l}\text { "Kesal karena } \\
\text { mengantuk" }\end{array}$ \\
\hline
\end{tabular}


cartoon-illustrationn-

tears-white-backgroundimage101823671

[diakses tanggal 1 Maret 2020]

5

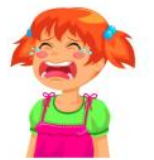

https://www.clipart.ema il/clipart/little-girl-

crying-clipart-

20085.html [diakses tanggal 3 Maret 2020]

6

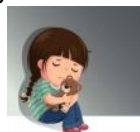

https://webcomicms. net/clipart-9270458-

cartoon-sadgirl [diakses tanggal 3 Maret 2020]

7

https://www.littleparach utes.com/category/feeli ngs/sadness/

8

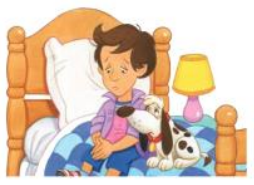

https://www.amazon.co m/Okay-Feel-GrowingGods-Kidsebook/dp/B01M16DFZO [diakses tanggal 3 Maret 2020]

\author{
Half Body + \\ Pewarnaan 2 \\ Dimensi + \\ Pendekatan Semi- \\ Realis + Tidak Ada \\ Background
}

Full Body +

Pewarnaan 2

Dimensi +

Pendekatan

Ilustratif + Objek

+ Background 1

Warna

Full Body +

Pewarnaan 2

Dimensi +

Pendekatan

Ilustratif + Objek

pendamping +

Background langit

Full Body +

Pewarnaan 2

Dimensi +

Pendekatan

Ilustratif + Objek

pendamping+

Setting lengkap

Full Body +

Pewarnaan 2

Dimensi +

Pendekatan

llustratif + Objek

pendamping+

Setting lengkap +

Warna

\section{"Sedih" \\ "Me- \\ "Sendirian \\ rengek" (lonely)"}

"Sedih" “Kehi- "Kesepian" langan"

$\begin{array}{lll}\text { "Sedih } & \text { "Tidak } & \text { "Sedih karena } \\ \text { karena tidak } & \text { nyaman } & \text { tidak punya }\end{array}$

ada yang " teman"

ajak main."

\begin{tabular}{|c|c|}
\hline $\begin{array}{l}\text { "Sedih } \\
\text { karena } \\
\text { kucingnva }\end{array}$ & "Capek" \\
\hline
\end{tabular}

\begin{tabular}{|c|c|c|}
\hline $\begin{array}{l}\text { "Sedih } \\
\text { karena } \\
\text { melihat } \\
\text { kakeknya }\end{array}$ & "Sepi" & $\begin{array}{l}\text { "Sedih karena } \\
\text { orang yang kau } \\
\text { sayangi } \\
\text { meninggalkanmu." }\end{array}$ \\
\hline
\end{tabular}

"Sedih

menangis" 


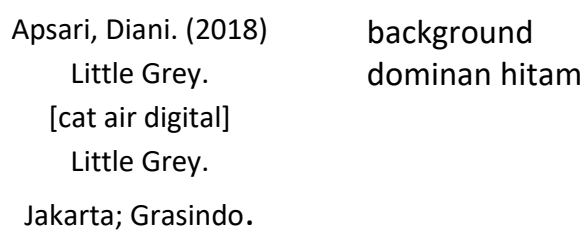

Dari hasil survey, rentang umur ternyata berpengaruh pada persepsi responden terhadap variasi visualisasi emosi sedih. Pengekspresian dan pemahaman emosi yang dipahami oleh anak usia 6-11 tahun adalah, mulai muncul rasa empati yang dapat semakin meningkat sesuai bertambahnya umur. Dan sesuai perkembangan bahasa yang semakin membaik, anak dapat semakin baik memahami emosinya, seperti yang dapat dilihat sebagai contoh, Biru (8 tahun) dan Malik Azka (10 tahun) dapat dengan lebih jelas memahami dan menjelaskan emosi yang ada di dalam visual. Selain itu, berbagai faktor dalam visual, seperti objek, warna, turut membangun persepsi kepada visual tersebut.

\section{Analisis Bahasa Visual Anak pada Buku "Little Grey"}

Buku cergam anak "Little Grey" berkisah tentang seorang anak bernama Anna, alias "Little Grey" yang berteman dengan sepasang kakek dan nenek bernama "Aunt Nina" dan "Uncle Jack", tetapi di tengah cerita, Anna harus menghadapi kejadian-kejadian menyedihkan yang mengakibatkan "Aunt Nina" meninggal dan "Uncle Jack" pergi dari kehidupannya. Tiga halaman yang dijadikan objek analisa adalah halaman yang menceritakan adegan duka tersebut. 


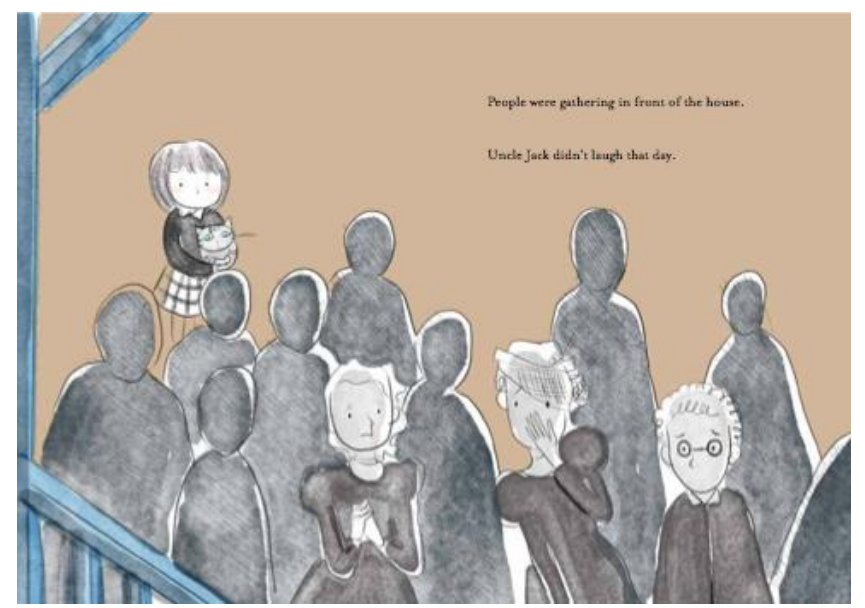

Gambar 4. Little Grey, halaman 49-50

(Sumber: Thalia \& Apsari, 2018)

Di Tabel 6, akan dijelaskan lebih lanjut mengenai pemetaan bahasa visual Gambar 4 sebagai berikut ini:

Tabel 6. Pemetaan Bahasa Visual Gambar 4

\begin{tabular}{lll}
\hline Cara Wimba & Tata Ungkapan Dalam & Bahasa Visual Anak \\
\hline Perkembangan naturalis; & Urutan di suatu latar; arah & Cara melihat latar berurutan \\
Perspektif; Stilasi + RWD; & lihat berurutan ke samping; & ke samping, penggambaran \\
Penggambaran ekspresif pada & Bentuk ditampilkan dengan & wajah yang ekspresif. \\
wajah; Momen opname & siluet; Cara khas; Komposisi & \\
\hline
\end{tabular}

(Sumber: Apsari \& Putra, 2020)

Pada Gambar 4, atau salah satu dari halaman spread/ bentang yang menceritakan adegan ketika Aunt Nina meninggal, lokasi cerita terjadi adalah di luar ruangan. Sehingga adegan ini dapat dikenali sebagai tata ungkap dalam identifikasi ruang. Ada juga penggambaran perspektif, yaitu orang-orang yang datang ke rumah Aunt Nina tampak lebih besar karena secara posisi lebih dekat dengan pembaca. Anna, digambarkan di belakang. Orang-orang yang dirasa tidak memberi identifikasi yang signifikan dihitamkan dalam siluet, sehingga wimba Anna tampak menonjol di belakang, memeluk kucingnya. Yang ingin diceritakan dari gambar 4 adalah, orang-orang tampak bersedih, tetapi Anna tidak mengetahui penyebabnya sehingga dia tampak khawatir. Narasi yang dituliskan, "People were gathering front of the house. Uncle Jack didn't laugh that day". 
Warna hitam dan abu-abu yang ditampilkan sebagai bayangan dan siluet orangorang yang datang ke rumah Anna dimaksudkan untuk memberi kesan misterius, karena yang ingin ditonjolkan adalah sosok Anna yang ada di belakang kerumunan, yang tidak tahu apa penyebab orang-orang tersebut tampak berduka.

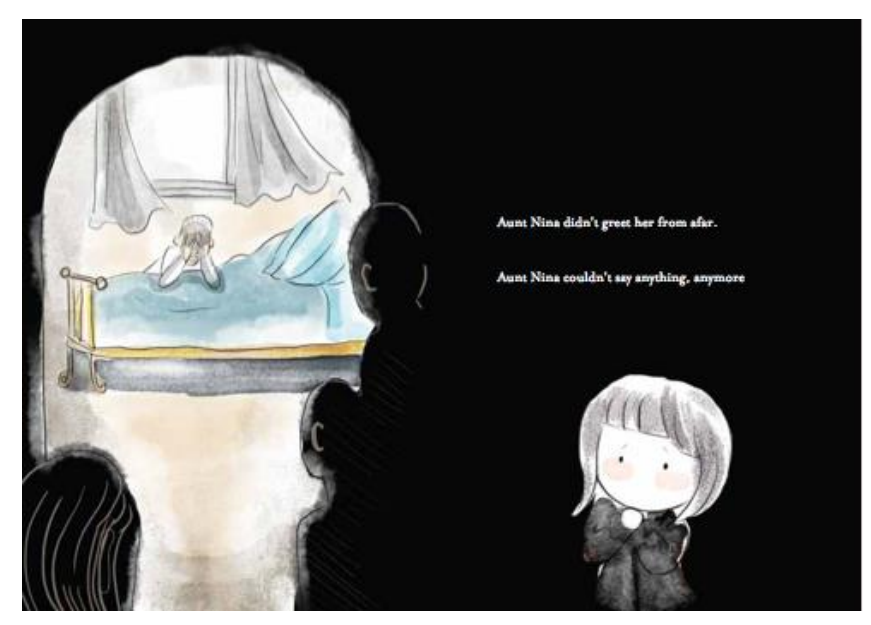

Gambar 5. Little Grey, halaman 51-52

(Sumber: Thalia \& Apsari, 2018)

Di Tabel 7, akan dijelaskan lebih lanjut mengenai pemetaan bahasa visual Gambar 5 sebagai berikut ini:

Tabel 7. Pemetaan Bahasa Visual Gambar 5

\begin{tabular}{lll}
\hline Cara Wimba & Tata Ungkapan Dalam & Bahasa Visual Anak \\
\hline Perkembangan naturalis; & Identifikasi Ruang; Objek yang & Cara melihat latar berurutan \\
Momen opname & penting dibuat skala besar, & ke samping, Ekspresi wimba \\
& arah lihat berurutan ke & Anna dan Uncle Jack \\
& samping; Bentuk ditampilkan & digambarkan sedih, \\
& dengan siluet; Cara & Background berwarna hitam \\
& khas;Komposisi & untuk mendukung suasana \\
& sedih. \\
\hline
\end{tabular}

(Sumber: Apsari \& Putra, 2020)

Sama seperti gambar 4, gambar 5 menggunakan teknik momen opname, yaitu merekam satu adegan saja dalam satu gambar. Di gambar ini, terlihat wimba Uncle Jack sedang tertunduk menangis di tempat tidur Aunt Nina, ruangan divisualisasikan berwarna biru pucat supaya kontras dengan tembok yang ada di luar ruangan, berwarna hitam. Wimba Anna yang diletakkan di depan dengan 
ekspresi sedih karena dia yang merupakan fokus dari cerita, lalu orang-orang disekitarnya digambarkan dengan siluet. Yang ingin diceritakan dari gambar 5 adalah, ternyata Uncle Jack sedang menangis di tempat tidur Aunt Nina, dan Anna memperhatikan dengan ekspresi sedih. Narasi yang dituliskan, "Aunt Nina didn't greet her from afar. Aunt Nina couldn't say anything, anymore". Warna hitam yang ditampilkan sebagai latar dimaksudkan sebagai penekanan untuk ekspresi emosi sedih dan berduka.

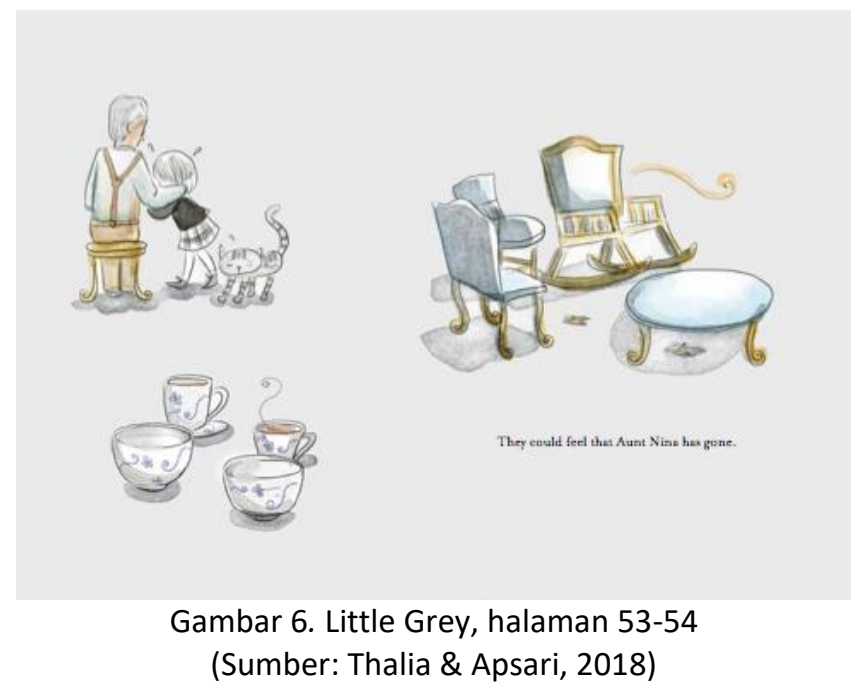

Di Tabel 8, akan dijelaskan lebih lanjut mengenai pemetaan bahasa visual Gambar 6 sebagai berikut ini:

Tabel 8. Pemetaan Bahasa Visual Gambar 6

\begin{tabular}{lll}
\hline Cara Wimba & Tata Ungkapan Dalam & Bahasa Visual Anak \\
\hline RWD; Ada objek penting yang & Objek yang penting dibuat & Cara melihat latar berurutan \\
diperbesar. & skala besar, arah lihat & ke samping, wimba Anna dan \\
& berurutan ke samping; Ada & Uncle Jack digambarkan \\
& komposisi & berpelukan; benda-benda \\
& & yang penting digambarkan \\
& besar. \\
\hline
\end{tabular}

(Sumber: Apsari \& Putra, 2020)

Dalam Gambar 6, benda-benda diletakkan dalam komposisi dan tanpa latar belakang. Wimba Uncle Jack dan Anna digambarkan berpelukan dan ada elemen dekoratif seperti air mata yang terciprat dari kepala Anna dan kucing 
peliharaannya. Ada juga elemen dekoratif angin yang bertiup untuk menggambarkan suasana sepi. Narasi yang tertulis, "They could feel Aunt Nina has gone." Warna abu-abu dan krem serta warna putih yang dominan, dimaksudkan untuk memunculkan kesan melankolis, tenang, dan sendu.

Dari tabel 5-7, maka dapat dilihat bahwa ternyata sistem visual yang diaplikasikan dalam buku "Little Grey" menggunakan gabungan dari sistem RuangWaktu-Datar dan sistem Naturalis-Perspektif-Momen Opname. Sistem RWD masing-masing terdapat dalam halaman yang telah dianalisa sebelumnya, karena digunakan dalam pendekatan bahasa visual tampak khas (seperti aneka tampak), identifikasi ruang, dan urutan di suatu latar. Sedangkan cara modern yang tergambar adalah pendekatan komposisi, skala gabungan, aspek warna, dan konsep perspektif, semua ini adalah pendekatan gaya visual modern yang menggunakan sistem NPM. Sehingga jika dihubungkan dengan gaya bahasa visual pembaca Little Grey, yaitu usia 6 tahun ke atas, maka kedua sistem tersebut sudah sesuai dengan periodisasi yang tercantum dalam skema perkembangan bahasa rupa dan gambar anak.

Korelasi antara Gambar Anak, Persepsi Visual Anak Terhadap Emosi, dan Ilustrasi Buku Cergam Anak “Little Grey” terhadap pemahaman rasa sedih.

Berdasarkan hasil analisis bahasa visual anak pada gambar, serta persepsi anak kepada variasi visualisasi emosi sedih dan ilustrasi buku cergam "Little Grey", telah ditemukan beberapa cara visualisasi yang sesuai digunakan untuk mengenalkan konsep emosi sedih pada anak. Ditemukan beberapa persamaan bahasa visual anak pada gambar anak dan ilustrasi dalam buku "Little Grey", yaitu 1) Tampak khas, untuk menyatakan hal yang dianggap penting melalui cara penggambaran wimba dari arah, bentuk, atau warna yang mudah dikenali; 2) Identifikasi ruang, untuk menyatakan ruang melalui cara penggambaran yang berhubungan dengan lokasi; 3) Urutan suatu latar, untuk menceritakan sejumlah latar cerita yang berurutan; dan 4) Komposisi, untuk menyatakan kesan penting 
dari wimba dapat tersampaikan, kesan ini dapat didukung dengan pewarnaan yang sesuai. Sehingga dapat dilihat terdapat kesamaan pada penggunaan sistem visual dari hasil analisis bahasa visual yang telah dilakukan pada gambar anak kontemporer serta ilustrasi yang ada di dalam buku "Little Grey".

Sistem RWD ditemukan pada gambar dan ilustrasi yang menggunakan metode (1) 'tampak khas', (2) 'ukuran wimba diperbesar', (3) 'identifikasi ruang', dan (4) 'urutan suatu latar'. Sistem NPM juga ditemukan pada gambar anak masa bagan (usia 7-9 tahun) dan masa realisme awal (9-11 tahun) dan ilustrasi buku "Little Grey", yang ditujukan untuk anak usia 6 tahun ke atas.

Pemahaman akan rasa sedih pun juga muncul dari eksperimen yang telah dilakukan. Dari 3 halaman bentang yang menunjukkan adegan sedih yang ada di dalam buku cergam "Little Grey", kebanyakan tokoh menampilkan ekspresi sedih, disertai dengan gestur dan setting yang membangun interpretasi suasana sedih dan duka dari naskah yang dibuat oleh penulis. Sesuai dengan hasil eksperimen yang dilakukan, semakin berkembangnya usia anak, anak akan semakin paham dan secara spesifik menjelaskan hubungan sebab-akibat yang ada di dalam suatu visual.

\section{KESIMPULAN}

Ada beberapa faktor yang membangun pemahaman anak akan rasa sedih dan kedukaan, terutama yang tergambar secara visual yang ada di dalam buku cergam anak. Bentuk visual yang menyampaikan pemahaman ini ini dapat berupa karakter yang dapat direlasikan dengan kehidupan anak-anak, warna-warni yang disukai anak, atau sesuatu yang memiliki unsur visual yang familiar dengan kehidupan anak. Salah satu cara untuk memahami unsur visual yang menarik bagi anak adalah, dengan mengamati gambar yang dihasilkan oleh anak-anak. Berdasarkan hasil observasi dan survey kepada anak-anak dengan rentang usia pembaca Little Grey, yaitu 6-11 tahun, diperoleh data bahasa visual anak yang 
khas, yang dapat dikorelasikan dengan bahasa visual ilustrasi yang ada di dalam Little Grey. Konsep tentang kesedihan dan kedukaan pun dibangun dengan ekspresi yang dimunculkan oleh tokoh yang ada di dalam ilustrasi, warna yang mendukung mood para pembaca, dan membangun suatu ikatan dengan narasi yang ada di halaman tersebut. Selain itu, perkembangan sosio-emosional para pembaca juga berpengaruh pada pemahaman pembaca kepada perasaan sedih, dan konsep berduka yang dihadirkan dalam "Little Grey".

Berdasarkan paparan yang telah dijelaskan sebelumnya, rekomendasi yang dapat dirumuskan untuk para ilustrator dan kreator buku anak yang hendak mengungkapkan unsur emosi dalam karya buku cergam anak adalah, visual yang ditampilkan haruslah mengadaptasi bagaimana anak membuat gambar yang dipahaminya, serta menunjukkan ekspresi wajah, gestur serta mimik yang sesuai dengan emosi yang hendak ditunjukkan, yang mana dalam buku Little Grey ini berfokus pada emosi kesedihan. Selain itu, konsep emosi ini pun dapat diperkuat dengan penggunaan palet warna yang melambangkan ekspresi sedih atau kedukaan. Seperti misalnya dalam fokus penelitian ini, emosi sedih dan berduka ditunjukkan dalam palet warna abu-abu, dan hitam yang dominan.

Dengan kata lain, pemahaman konsep emosi dari suatu buku cergam anak tidak bisa berdiri sendiri hanya dengan visual dari ilustrasi saja, tetapi merupakan sebuah konsep satu "dunia" yang utuh, yang terjalin antara anak-anak sebagai pembaca, dan buku cergam anak sebagai media pemahaman emosi. Dengan adanya pemahaman akan dunia tersebut, kita dapat memperoleh perspektif baru bagaimana pemahaman tentang emosi dapat dimengerti oleh anak-anak.

Berdasarkan hasil simpulan, banyak faktor yang dapat membangun pemahaman anak terhadap konsep emosi yang yang diperkenalkan dalam buku cergam anak. Adapun saran yang dipertimbangkan penulis adalah perlunya penelitian yang lebih mendalam dan komprehensif dengan tujuan melakukan studi komparatif bagi pemahaman jenis emosi yang lain, seperti pemahaman 
emosi senang dan marah dalam penelitian berikutnya. Diharapkan dengan mengikutsertakan variabel yang lain, seperti pengungkapan ekspresi/emosi yang ditunjukkan dengan tanda-tanda visual seperti ekspresi wajah, gestur atau body language dan citra/ konsep warna, dalam pengenalan emosi-emosi yang lainnya, dapat semakin memperkaya referensi para kreator ataupun para penggiat yang memiliki minat dalam dunia cergam anak.

\section{DAFTAR PUSTAKA}

AD, Y. (2018) 'Konsep Perkembangan Kognitif Perspektif Al-Ghazali dan Jean Piaget', KONSELI: Jurnal Bimbingan dan Konseling (E-Journal), 5(2), pp. 97104. doi: 10.24042/kons.v5i2.3501.

Bariola, E., Gullone, E. and Hughes, E. K. (2011) 'Child and Adolescent Emotion Regulation: The Role of Parental Emotion Regulation and Expression', Clinical Child and Family Psychology Review, 14, pp. 198-212. doi: 10.1007/s10567-011-0092-5.

Basuki, A. (2015) Makna Warna Dalam Desain, http://basuki.lecturer.pens.ac.id/lecture/MaknaWarnaDalamDesain.pdf. Available at: http://basuki.lecturer.pens.ac.id/lecture/MaknaWarnaDalamDesain.pdf (Accessed: 30 April 2020).

Berk, L. E. (2013) Child development (9th Ed.). New York: Pearson.

Dyah RA., R. (2017) Perancangan Warna Dalam Ilustrasi Buku Berjudul 'Arafura' Yang Menggunakan Teknik Kinegram. Universitas Multimedia Nusantara. doi: 10.1136/ip.2010.029629.

Gennep, A.V., Kertzer, D., Vizedom, M.B., dan Caffee, G.L. (2018) The Rites of Passage, Second Edition. Chicago: University of Chicago Press. doi: 10.7208/chicago/9780226629520.001.0001.

Gerber, R. J., Wilks, T. and Erdie-Lalena, C. (2011) 'Developmental Milestones 3: 
Social-emotional Development', Pediatrics in Review, 32(12), pp. 533-536. doi: 10.1542/pir.32-12-533.

Hanisha, F., Djalari, Y. A. and Hutama, K. (2018) ‘Bahasa Visual, Gambar Anak, dan Ilustrasi Pada Buku Cergam Anak', Jurnal Seni dan Reka Rancang: Jurnal IImiah Magister Desain, 1(1), pp. 63-82. doi: 10.25105/jsrr.v1i1.3878.

Hladíková, H. (2014) ‘Children's Book Illustrations: Visual Language of Picture Books.', CRIS - Bulletin of the Centre for Research and Interdisciplinary Study, pp. 19-31. Available at: https://www.praguecollege.cz/hubfs/Docs/Bulletin/crisbulletin_2014_01 _web_v3.pdf.

Howard, H. G. (2010) 'Guiding and Hiding: Teaching our Children about Grief through the Use of Cultural Artifacts'. Virginia: Washington and Lee University.

Inarah, F. A. (2017) Analisis Karakteristik Gambar Anak Menurut Viktor Lowenfeld dan L. Brittain. Universitas Negeri Jakarta.

Indrayati, R. I., Setyawan, P. and Saidi, A. I. (2018) 'Narasi Visual Kematian pada Ilustrasi Buku Cerita Rakyat Anak Indonesia', Jurnal Budaya Nusantara, 2(1), pp. 203-209. doi: 10.36456/b.nusantara.vol2.no1.a1713.

Kartaatmadja, H. (2015) 'Studi Ilustrasi Karakter Anak Indonesia untuk Rekomendasi Pembuatan Buku Cergam Anak', Prosiding Seminar Nasional Cendekiawan, II, pp. 145-159. Available at: http://www.trijurnal.lemlit.trisakti.ac.id/index.php/semnas/article/view/ 129.

McCannon, D., Thonton, S. and Williams, Y. (2008) The Encyclopedia of Writing and Illustrating Children's Book : From Creating Characters to Developing Stories, A Step-By-Step Guide to Making Magical Picture Books. Edited by L. Dalby. Philadelphia: Running Press.

Novia, C. E., Waluyanto, H. D. and Zacky, A. (2016) ‘Perancangan Buku Bergambar 
dengan Daya Tarik Pop-Up tentang Manajemen Emosi untuk Anak-Anak Usia 4-6 Tahun', Jurnal DKV Adiwarna, Universitas Kristen Petra, 1(8), pp. $1-11$.

Salam, S. (2017) Seni Ilustrasi : Esensi - Sang Ilustrator - Lintasan - Penilaian. Makassar: Badan Penerbit UNM Universitas Negeri Makassar.

Salisbury, M. (2004) Illustrating Children's Books : Creating Pictures for Publication. London: Quarto Book.

Steyn, M. and Moen, M. (2019) 'Drawing sadness: what are young children telling us?', Early Child Development and Care. Routledge, 189(1), pp. 79-93. doi: 10.1080/03004430.2017.1301936.

Streit, A. K. (2012) 'Memahami Gaya Menggambar Anak-Anak untuk Membuat Buku Cerita Anak', Jurnal Rupa Rupa Universitas Bunda Mulia, 1(1), pp. 4147. Available at: https://docplayer.info/53977262-Memahami-gayamenggambar-anak-anak-untuk-membuat-buku-cerita-anak.html.

Tabrani, P. (2012) Bahasa Rupa. Bandung: Penerbit Kelir.

Thalia, S. and Apsari, D. (2018) Little Grey. Jakarta: Grasindo. 